\title{
RETRACTION
}

Genes \& Development 14: 313-327 (2000)

\section{Retraction: Transient depletion of xDnmt1 leads to premature gene activation in Xenopus embryos}

Irina Stancheva and Richard R. Meehan

Genes \& Development is retracting this article after an investigation led by the University of Edinburgh found that Dr. Irina Stancheva inappropriately manipulated data presented in Figures $6 \mathrm{~F}, 8 \mathrm{~B}, 8 \mathrm{D}$, and $8 \mathrm{~F}$ and likely in Figure $3 \mathrm{~A}$. Based on the University of Edinburgh's investigation panel findings, the editors have decided the best course of action is to retract the paper. Dr. Stancheva and Dr. Meehan could not be reached and therefore have not agreed to the text of this Retraction.

doi: $10.1101 / \operatorname{gad} .327486 .119$ 


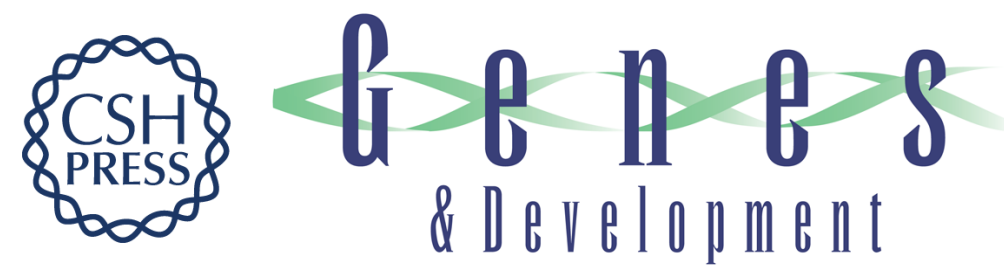

\section{Retraction: Transient depletion of xDnmt1 leads to premature gene activation in Xenopus embryos}

Irina Stancheva and Richard R. Meehan

Genes Dev. 2019, 33:

Access the most recent version at doi:10.1101/gad.327486.119

\section{Related Content Transient depletion of xDnmt1 leads to premature gene activation in Xenopus embryos \\ Irina Stancheva and Richard R. Meehan \\ Genes Dev. February , 2000 14: 313-327}

\section{License}

Email Alerting Receive free email alerts when new articles cite this article - sign up in the box at the top Service right corner of the article or click here.

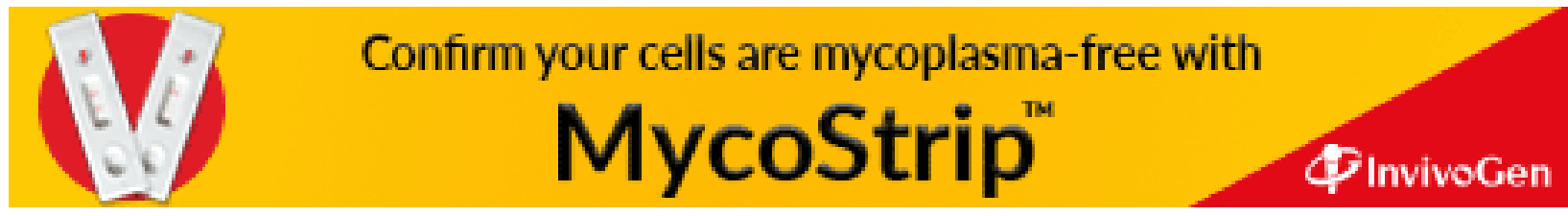

